\title{
MAKNA TANAMAN PADA PERLENGKAPAN UPACARA PERKAWINAN ADAT SUKU DAYAK UUD DANUM
}

\section{PLANTS MEANING IN TRADITIONAL WEDDING CEREMONY EQUIPMENT OF DAYAK UUD DANUM ETHIC GROUP}

\author{
${\text { Ursula Dwi Oktaviani }{ }^{*} \text {, Andri Andri }{ }^{2} \text {, Benediktus Ege }}^{3}$ \\ Pendidikan Bahasa dan Sastra Indonesia, STKIP Persada Khatulistiwa Sintang, \\ Indonesia $^{1}$ Pendidikan Matematika, STKIP Persada Khatulistiwa Sintang, Indonesia ${ }^{2}$, \\ Pendidikan Biologi, STKIP Persada Khatulistiwa Sintang, Indonesia ${ }^{3}$ \\ $\underline{\text { ursuladwioktaviani@gmail.com }}{ }^{1}$, andry_tkr@yahoo.com ${ }^{2}, \underline{\text { ama tamo@yahoo.com }}^{3}$ \\ *penulis korespondensi
}

\begin{tabular}{ll}
\hline Info Artikel & ABSTRAK \\
\hline Sejarah artikel: & Penelitian pada upacara perkawinan adat suku Dayak Uud Danum \\
Diterima: & menggunakan kajian semiotika Roland Barthes. Tanda-tanda dianalisis \\
9 Desember 2020 & melalui penanda (signifier), petanda (signified), tanda denotative \\
Direvisi: & (denotative sign), penanda konotatif (connotative signifier), petanda \\
23 Desember 2020 & konotatif (connotative signified), dan tanda konotatif (connotative sign). \\
Disetujui: & Penelitian ini bertujuan untuk mendeskripsikan makna tanaman pada \\
20 Januari 2021 & perlengkapan upacara perkawinan adat suku Dayak Uud Danum. Metode \\
& yang digunakan pada penelitian ini yakni metode kualitatif dengan kata \\
Kata kunci: & lain penelitian ini mengkaji data secara mendalam tentang semua \\
Tanaman, upacara & kompleksitas yang ada dalam penelitian tanpa melalui prosedur statistik \\
perkawinan adat, & atau bentuk hitungan yang lainnya. Instrument penelitian yang digunakan \\
Dayak Uud Danum, & pada penelitian ini yaitu: lembar wawancara, lembar observasi dan \\
semiotika & dokumentasi. Data pada penelitian ini yakni tanaman pada perlengkapan \\
& upacara perkawinan adata suku Dayak Uud Danum. Teknik pengumpulan \\
& data pada penelitian ini terdiri dari observasi partisipan, wawancara \\
& terbuka dan mendalam, serta dokumentasi. Teknik analisis data yakni \\
& domain, taksonomi, komponensial. Terdapat 6 (enam) jenis tanaman yang \\
& digunakan pada perlengkapan upacara perkawinan adat suku Dayak Uud \\
& Danum, hasil dari analisis ditemukan beberapa makna yakni makna \\
konotatif, makna denotatif, dan mitos.
\end{tabular}

\begin{tabular}{|c|c|}
\hline Article Info & ABSTRACT \\
\hline $\begin{array}{l}\text { Article history: } \\
\text { Diterima: } \\
\text { 9 December } 2020 \\
\text { Direvisi: } \\
\text { 23 December } 2020 \\
\text { Disetujui: } \\
\text { 20 January } 2021 \\
\text { Keywords: } \\
\text { Plants, traditional } \\
\text { wedding ceremony, } \\
\text { Dayak Uud Danum, } \\
\text { semiotics }\end{array}$ & $\begin{array}{l}\text { Research on the customary wedding ceremony of the Dayak Uud Danum } \\
\text { tribe used a semiotic study by Roland Barthes. Signs were analyzed by } \\
\text { means of a signifier, a signified, a denotative sign, a connotative sign, the } \\
\text { connotative signified, and the connotative sign. This study aims to describe } \\
\text { the meaning of plants in the traditional wedding ceremony equipment of } \\
\text { the Dayak Uud Danum ethic group. The method used in this study is a } \\
\text { qualitative method, in other words, this study examines data in depth about } \\
\text { all the complexities which exist in research without going through } \\
\text { statistical procedures or other forms of calculation. The research } \\
\text { instruments used in this study were: interview sheets, observation sheets } \\
\text { and documentation. The data in this study were plants in the traditional } \\
\text { wedding ceremony equipment of the Dayak Uud Danum ethic group. Data } \\
\text { collection techniques in this study consisted of participant observation, } \\
\text { open and in-depth interviews, and documentation. Data analysis } \\
\text { techniques, namely domain, taxonomy, and components. There are } 6 \text { (six) } \\
\text { types of plants used in the traditional wedding ceremony equipment of the }\end{array}$ \\
\hline
\end{tabular}


Dayak Uud Danum tribe, the results of the analysis found several meanings, namely connotative meaning, denotative meaning, and myth.

\section{PENDAHULUAN}

Suku Dayak di Kalimantan Barat terdiri dari 151 subethnis (Alloy, Albertus, Bamba, \& Istiyani, 2008), salah satunya adalah sub etnis Dayak Uud Danum (suku Dayak Uud Danum) yang ada Kecamatan Serawai dan Ambalau Kabupaten Sintang. Suku Dayak Uud Danum tersebut masih mempertahankan adat dan tradisi dalam berbagai upacara adat dan kegiatan sehari-hari. Adat dan tradisi dalam penggunaan sumber daya alam hutan oleh suku tertentu termasuk suku Dayak Uud Danum merupakan kearifan lokal. Kearifan lokal atau sering disebut Local Wisdom adalah semua bentuk pengetahuan, keyakinan, pemahaman, atau wawasan serta adat kebiasaan atau etika yang menuntun perilaku manusia dalam kehidupan di dalam komunitas ekologis (Keraf, 2002).

Bentuk-bentuk kearifan lokal suku Dayak Uud Danum yaitu pengetahuan tradisional (knowlegde indegenous) atau juga diistilahkan dengan kearifan tradisional tentang kelahiran, perkawinan, perceraian, pengobatan tradisional dan upacara kematian. Masyarakat suku dayak $U u d$ Danum masih menjaga tradisi pernikahan adat dengan sangat baik. Tanaman yang digunakan pada upacara perkawinan adat memiliki makna agar pasangan yang menikah dapat menjaga kehidupan rumah tangga dengan penuh tanggungjawab. Tanaman yang digunakan menjadi simbol dan sekaligus pengingat bagi pasangan yang menikah tersebut.

Ada beberapa permasalahan tentang kearifan lokal dimasyarakat antara lain: (1) Penyampaian informasi tentang material acara adat baik berupa barang logam, tumbuhan maupun hewan serta teknik penggunaannya hanya terbatas penyampaian dari orang tua kepada anak dan atau cucu secara turun temurun oleh sebagian penduduk saja (Yusro, Mariani, Diba, \& Ohtani, 2014), (2) Pengaruh budaya asing yang menggunakan obat modern atau treatmen kesehatan barat, secara perlahan mengambil pengobatan tradisional (Kustiawan, 2007), (3) Kondisi hutan di Kalimantan Barat yaitu degradasi hutan di Kalimantan Barat setiap tahunnya terus meningkat akibat semakin luasnya pembukaan lahan untuk pengembangan hutan tanaman industri (HTI), perkebunan kelapa sawit, pembalakan liar, dan ladang berpindah mengancam kelestarian plasma nutfah, spesies langka dan endemik yang ada khususnya tumbuhan yang memiliki potensi sebagai tumbuhan obat (Takoy, Linda, \& Lovadi, 2013). Berbagai permasalahan tersebut dapat mengancam kelestarian pengetahuan tradisional suku Dayak Uud Danum yang berhubungan dengan kearifan lokal dalam tradisi perkawinan. Dokumentasi pengetahuan adat dalam mengelola sumber daya di hutan, baik untuk pemanfaatan pada acara perkawinan. Tanaman yang terdapat pada perlengkapan upacara 
perkawinan adat suku Dayak Uud Danum dianalisis menggunakan semiotika Roland Barthes.

Semiotika Roland Barthes tidak terlepas dari mitos sebagai bagian dari penelitiannya. Mitos adalah cerita suatu bangsa tentang dewa dan pahlawan zaman dahulu, mengandung penafsiran tentang asalusul semesta alam, manusia, dan bangsa tersebut, mengandung arti mendalam yang diungkapkan dengan cara gaib (Kemendikbud, 2016). Roland Barthes menyatakan bahwa mitos adalah semacam wicara, segalanya dapat menjadi mitos asal hal itu disampaikan lewat wacana (discourse). Mitos tidak didefinisikan oleh objek pesannya, tetapi oleh caranya menyatakan pesan (Barthes, 2010). Mitos merupakan produk kelas sosial yang mencapai dominasi melalui sejarah tertentu: maknanya, peredaran mitos tersebut mesti dengan membawa sejarahnya, namun operasinya sebagai mitos mengaburkan hal tersebut dengan menampilkannya sebagai sesuatu yang alami, dan bukan bersifat historis atau sosial tetapi lebih berdimensi sosial atau politik (Putra \& Yohana, 2015).

Semiotika merupakan ilmu yang mempelajari tentang tanda yang mana tanda-tanda tersebut mewakili suatu pesan atau informasi yang bersifat komunikatif. Semiotika sebagai studi tentang tanda dan segala sesuatu yang berkaitan dengannya seperti cara berfungsinya, hubungannya dengan tanda-tanda lain, pengirimannya, dan penerimaannya oleh mereka yang mempergunakannya (Zoest, 1993). Ada pula yang mengatakan semiotika sebagai ilmu yang secara sistematik mempelajari tanda-tanda dan lambang-lambang, dan proses perlambangan (Pradopo,
2007). Dengan demikian semiotika juga bertautan dengan proses-proses 'signifikansi' (penandaan) dan dengan proses-proses 'komunikasi', yakni sebuah alat atau media tempat maknamakna ditetapkan dan dipertukarkan.

Semiotika bukanlah ilmu yang mempunyai sifat kepastian, ketunggalan, dan objektivitas, melainkan dibangun oleh pengetahuan yang lebih terbuka bagi aneka interpretasi (Tinarbuko, 2009).

Tabel 1. Peta Tanda Roland Barthes

\begin{tabular}{|ll|r|}
\hline 1. & $\begin{array}{l}\text { Signifier } \\
\text { (petanda) }\end{array}$ & $\begin{array}{l}\text { 2. } \\
\text { Signified } \\
\text { (petanda) }\end{array}$ \\
\cline { 1 - 1 } 3. & $\begin{array}{l}\text { Denotative sign (tanda } \\
\text { denotatif) }\end{array}$ \\
\hline 4. & $\begin{array}{l}\text { CONNOTATIVE } \\
\text { SIGNIFIER (PENANDA } \\
\text { KONOTATIF) }\end{array}$ & $\begin{array}{l}\text { SONNOTATIVE } \\
\text { SIGNIFIED } \\
\text { (PETANDA } \\
\text { KONOTATIF) }\end{array}$ \\
\hline \multicolumn{2}{|c|}{ 6. CONNOTATIVE SIGN (TANDA KONOTATIF) } \\
\hline
\end{tabular}

Sumber: (Sobur, 2016)

Dari tabel Barthes di atas terlihat bahwa tanda denotatif (3) terdiri atas penanda (1) dan petanda (2). Akan tetapi, pada saat bersamaan, tanda denotative adalah juga penanda konotatif (4). Dengan kata lain, hal tersebut merupakan unsur material: hanya jika anda mengenal tanda "singa", barulah konotasi seperti harga diri, kegarangan, keberanian menjadi mungkin Cobley dan Jansz dalam (Sobur, 2016). Jadi dalam konsep Barthes, tanda konotatif tidak sekedar memiliki makna tambahan namun juga mengandung kedua bagian tanda denotatif yang melandasi keberadaannya (Sobur, 2016).

\section{METODE}

Metode yang digunakan pada penelitian ini adalah metode kualitatif. Jenis pendekatan yang dilakukan pada penelitian ini menggunakan analisis 
Semiotik. Analisis semiotik pada penelitian ini menggunakan pendekatan semiotik Roland Barthes terhadap tanaman pada perlengkapan upacara perkawinan adat suku dayak Uud Danum.

Subyek penelitian pada penelitian bersifat snowball sampling. Sampel sumber data pada tahap awal memasuki lapangan dipilih orang yang memiliki kekuasaan/kekuatan dan otoritas pada situasi sosial atau objek yang diteliti, sehingga mampu "membukakan pintu" kemana saja peneliti akan melakukan pengumpulan. Informan ditentukan berdasarkan keterangan dari tokoh masyarakat adat, kepala suku, kepala desa, kepala kampung, dewan adat dayak (DAD) Suku Dayak Uud Danum dan sumber terpercaya lainnya yang mengetahui hal-hal yang berkaitan erat dengan penelitian yang akan dilakukan.

Instrument penelitian yang digunakan pada penelitian ini yaitu: lembar wawancara, lembar observasi dan dokumentasi. Data pada penelitian ini yakni tanaman pada perlengkapan upacara perkawinan adata suku Dayak Uud Danum. Teknik pengumpulan data pada penelitian ini terdiri dari observasi partisipan, wawancara terbuka dan mendalam, serta dokumentasi. Teknik analisis data yakni domain, taksonomi, komponensial.

\section{HASIL DAN PEMBAHASAN}

\section{Kahat}

Kahat dalam bahasa Indonesia adalah pinang (areca catechu L) merupakan nama berbagai pohon dan buahnya yang termasuk kelompok palem, bentuk, jenis, dan kegunaannya beraneka ragam, tumbuhnya ada yang berumpun dan ada yang tunggal (Kemendikbud, 2016).

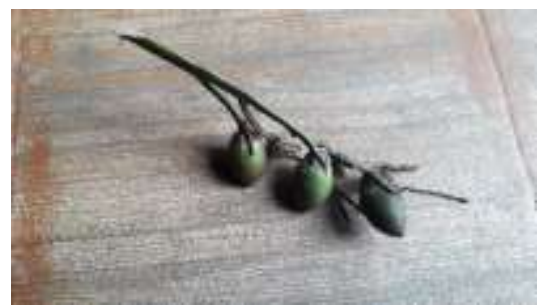

Gambar 1. Kahat (pinang)

\section{Konotatif}

Pada upacara perkawinan ada suku Dayak Uud Danum, kahat (pinang) dimaknai sebagai tanaman yang bisa mempersatukan kedua mempelai dan kedua mempelai saling melengkapi dalam hidup berumah tangga. Bagian yang dimanfaatkan pada tanaman ini yakni buahnya.

Mitos

Kahat dikunyah bersama-sama oleh kedua mempelai, dengan tujuan pasangan pengantin baru saling melengkapi dan selalu bersama sehidup semati, baik dalam suka maupun duka.

\section{Lout}

Lout dalam bahasa Indonesia sirih (piper betle L.) merupakan tumbuhan merambat di pohon lain, daunnya berasa agak pedas, biasa dikunyah bersama dengan pinang, kapur, gambir sebagai makanan yang mencandu, penguat gigi, dan sebagainya (Kemendikbud, 2016). 


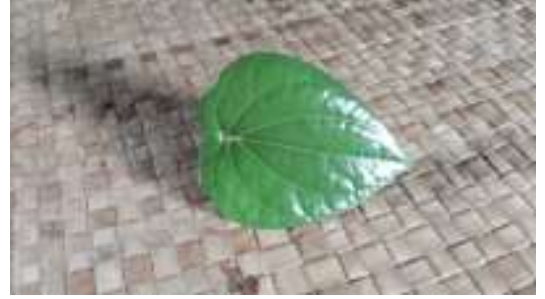

Gambar 2. Lout (daun sirih)

\section{Konotatif}

Lout (sirih) pada upacara perkawinan adat suku Dayak Uud Danum dimaknai sebagai tanaman yang melambangkan sebuah kesetiaan antara suami dan istri. Bagian yang digunakan pada tanaman ini adalah daunnya.

\section{Mitos}

Lout dimakan/dikunyah bersamaan dengan buah pinang, supaya kedua mempelai bisa saling setia dalam hidup berumah tangga.

\section{Savang Bohijau}

Savang bohijau dalam bahasa Indonesia renjuang (Cordyline fruticosa $L$ ) merupakan tanaman perdu dari kelas monolydoneae yang biasanya di tanam sebagai tanaman hias di pekarangan, taman, atau kuburan, maupun dipakai sebagai tanaman pagar.

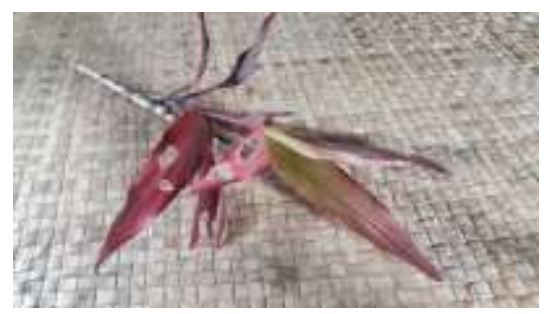

Gambar 3. Savang bohijau (renjuang)

\section{Konotatif}

Savang bohijau wajib ada pada upacara adat perkawinan suku dayak Uud Danum, tanaman ditanam bersamaan oleh kedua mempelai yang bermakna bahwa sebuah kehidupan berumah tangga telah dimulai bersama dan supaya rumah tangga yang dibangun tidak goyah oleh segala macam godaan. Bagian tanaman yang digunakan adalah pucuknya.

\section{Mitos}

Savang bohijau dipercaya sebagai tanaman penolak sial dalam rumah tangga, tanaman tersebut ditanam oleh kedua mempelai.

\section{Somo Morum}

Somo morum dalam bahasa Indonesia cocor bebek (Kalanchoe pinnata Lam.Pers) adalah tanaman hias dengan banyak manfaat. Tanaman hias ini mudah tumbuh di parit, kebun, bahkan tumbuh subur di tanah berbatu. Daunnya tebal berdaging dan mengandung banyak air, sedangkan batangnya lunak dan memiliki ruas. Cocor bebek memiliki bunga majemuk berwarna merah muda. Cocor bebek merupakan tanaman dengan ciri-ciri yaitu daunnya yang tebal dan berair, bunga yang berwarna hijau muda kekuningan, dan dapat tumbuh hingga 1-2 m. Tanaman ini tumbuh di daerah tropis seperti Vietnam, Filipina, dan Indonesia (Putri \& Hasanah, 2017).

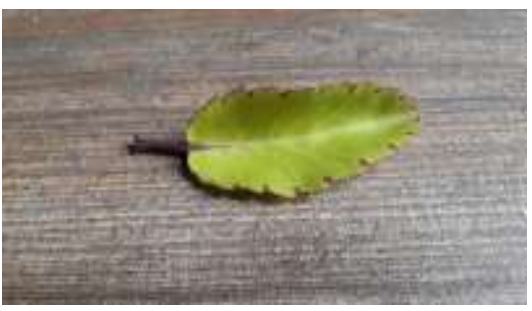

Gambar 4. Somo morum (cocor bebek)

\section{Konotatif}

Somo morum merupakan tanaman yang tidak boleh ketinggalan pada 
perlengkapan upacara perkawinan adat suku Dayak Uud Danum karena tanaman ini dimaknai sebagai simbol kesuburan, selalu tumbuh, dan hidup maksudnya sesuai dengan tanaman tersebut bahwa dalam sebuah perkawinan memiliki keturunan. Bagian yang digunakan adalah daunnya.

\section{Mitos}

Somo morum dipercaya dapat memberikan kehidupan perkawinan yang selalu tumbuh dan hidup. Somo morum dihancurkan/ditumbuk dan dioleskan di kepala kedua mempelai.

\section{Uwi Sohkok}

Uwi sohkok dalam bahasa Indonesia rotan sega (Calamus caesius Blume) merupakan tumbuhan menjalar yang batangnya digunakan untuk berbagai barang atau perabot (seperti kursi, tali, gelang) (Kemendikbud, 2016).

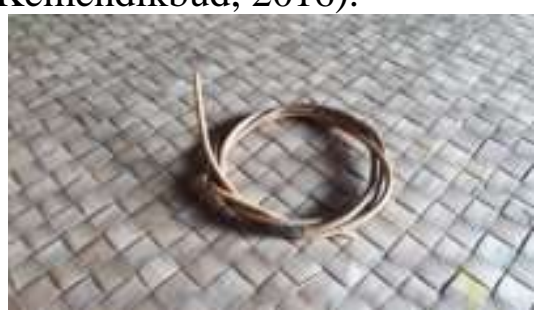

Gambar 5. Uwi sohkok (rotan sega)

\section{Konotatif}

Uwi sohkok dimaknai sebagai simbol penguat ikatan hubungan suami dan istri dalam berumah tangga. Bagian tanaman yang digunakan adalah batangnya.

\section{Mitos}

Mengalungkan uwi sohkok du leher kedua mempelai dipercayai dapat memperkuat ikatan suami dan istri dan hidup berumah tangga yang panjang atau langgeng.

\section{Talik Togang}

Talik togang dalam bahasa Indonesia akar bajakah tengang (Spatholobus Littoralis Hassk) merupakan tanaman herbal yang dapat dimanfaatkan semua bagiannya (Saputera \& Ayuchecaria, 2018).

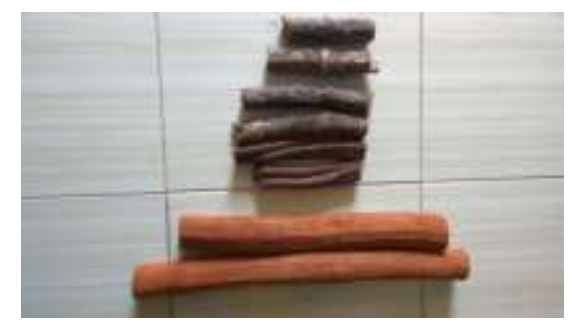

Gambar 6. Talik togang (akar bajakah)

\section{Konotatif}

Talik togan dimaknai sebagai penguat ikatan pernikahan, supaya langgeng sampai maut memisahkan, karena tanaman tersebut dianggap tanaman yang kuat. Bagian yang digunakan adalah batangnya.

\section{Mitos}

Talik togan dipercaya penguat roh pada sebuah pernikahan, tanaman tersebut digelangkan/diikatkan ke tangan kedua mempelai.

\section{PENUTUP}

Berdasarkan hasil analisis pada perlengkapan upacara perkawinan adat suku Dayak Uud Danum terdapat 6 (enam) jenis tanaman yang digunakan untuk dijadikan sebagai perlengkapan upacara perkawinan adat, serta ditemukan beberapa makna yakni 1) 
makna denotatif yang merupakan makna sebenarnya (realistis) yang sesuai gambar, 2) makna konotatif yang merupakan makna yang tidak tampak (tersembunyi) dari suatu apa yang tampak seperti gambar, dan 3) mitos dalam hal ini tidak ada hubungan berdasarkan kebenaran, tetapi hubungan berdasarkan penggunaan sehingga manusia menggunakan mitos berdasarkan kebutuhan.

\section{DAFTAR PUSTAKA}

Alloy, S., Albertus, Bamba, J., \& Istiyani, C. P. (2008). Mozaik Dayak: Keberagaman Subsuku dan Bahasa Dayak di Kalimantan Barat. Pontianak: Institut Dayakologi.

Barthes, R. (2010). Membedah MitosMitos Budaya Massa: Semiotika atau Sosiologi Tanda, Simbol, dan Representasi. Yogyakarta: Jalasutra.

Kemendikbud, B. P. (2016). Agustus 24). KBBI Daring. Retrieved from kbbi.kemdikbud.go.id: https://kbbi.kemdikbud.go.id

Keraf, A. S. (2002). Etika Pengelolaan Sumber Daya Alam dan Lingkungan Hidup. Environmental ethics (pp. 81117). Jakarta: UNIKA Atma Jaya.

Kustiawan, I. (2007). Kajian Permasalahan Dan Kebijaksanaan Pengendalian. Bandung: Institut Teknologi Bandung.

Pradopo, R. D. (2007). Pengkajian Puisi. Yogyakarta: Gadjah mada University Press.
Putra, W. W., \& Yohana, N. (2015). Representasi Makna Simbol Ragam Hias pada Rumah Lontiok Kabupaten Kampar Riau (Analisis Semiotika Roland Barthes Mengenai Makna Simbol Rumah Lontiok di Desa Ranah Air Tiris Kabupaten Kampar). JOM FISIP Volume 2 No 1, 1-15.

Putri, V., \& Hasanah, A. N. (2017). Review: Profiling Senyawa Kuersetin Dari Tanaman Cocor Bebek (Kalanchoe pinnata) dengan Menggunakan Berbagai Metode Analisis. Farmaka Vol 15 (1), 134-145.

Saputera, M. M., \& Ayuchecaria, N. (2018). Uji Efektivitas Ekstrak Etanolik Batang Bajakah Tampala (Spatholobus littoralis Hassk.) Terhadap Waktu Penyembuhan Luka. Jurnal Ilmiah Ibnu Sina, 3(2), 318327.

Sobur, A. (2016). Semiotika Komunikasi. Bandung: Rosda.

Takoy, D. M., Linda, R., \& Lovadi, I. (2013). Tumbuhan Berkhasiat Obat Suku Dayak Seberuang Di Kawasan Hutan Desa Ensabang Kecamatan Sepauk Kabupaten Sintang. Protobiont Vol 2 (3), 122 - 128.

Tinarbuko, S. (2009). Semiotika Komunikasi Visual (Edisi Revisi). Yogyakarta: Jalasutra.

Yusro, F., Mariani, Y., Diba, F., \& Ohtani, K. (2014). Inventory of Medicinal Plants for Fever Used by Four Dayak. Kuroshio Science 8-1, 33-38. 
Oktaviani, Andri, dan Ege/Makna Tanaman pada Perlengkapan Upacara... Stilistika: Jurnal Pendidikan Bahasa dan Sastra Vol.14, No. 1, Januari 2021 Hal 14-21

Zoest, A. V. (1993). Semiotika: Dengannya. Jakarta: Yayasan Tentang Tanda, Cara Kerjanya dan Apa yang Kita Lakukan Sumber Agung. 